\title{
Anaphylactic shock with pulmonary eosinophilic infiltration due to honeybee attack in a donkey: case report
}

[Choque anafilático com infiltração eosinófila pulmonar devido a ataque de abelhas em um burro: relato de caso]

\author{
E. Zache ${ }^{(\mathbb{D})}$, J.F. Cajueiro (iD), A.Q. Andrade Neto ${ }^{(\mathbb{D})}$, L. Almeida ${ }^{(\mathbb{D}}$, R.R. Colares ${ }^{(\mathbb{D})}$, \\ J.A.B. Afonso (iD), M.I. Souza (iD), A. Arenales*(D) \\ Universidade Federal Rural de Pernambuco, Clínica de Bovinos, \\ Campus Garanhuns, Garanhuns, PE, Brasil
}

\begin{abstract}
A case of a donkey attacked by Africanized honeybee is reported here with clinical signs of agitation, dehydration, congestion of the ocular mucous membranes, tongue edema, tachycardia and inspiratory dyspnea, and progression to death. At necropsy, diffuse, severe subcutaneous edema at face and cervical regions and severe diffuse pulmonary hyperemia with abundant edema without parenchymal collapse were observed. Microscopically, marked, diffuse deep dermis and panniculus carnosus edema and marked diffuse alveolar edema, with moderate population of eosinophils predominantly around larger caliber vessels were noted. The final diagnosis of anaphylactic shock was supported by history, clinical signs, and anatomic pathology findings. This is the first report of a honeybee attack with pulmonary eosinophilic infiltration in a mammal.
\end{abstract}

Key words: apitoxin, melittin, Apis mellifera mellifera, Apis mellifera scutellata

\section{RESUMO}

Descreve-se um caso de ataque de abelha africanizada em um burro, com sinais clínicos de agitação, desidratação, mucosas oculares congestas, edema de língua, taquicardia e dispneia inspiratória, com progressão e morte. Na necropsia, foram verificados edema subcutâneo difuso grave nas regiões de face e cervical, hiperemia pulmonar difusa grave com edema abundante e sem colapso do parênquima. Microscopicamente, foram observados edema marcado difuso na derme profunda e panículo carnoso e edema alveolar difuso acentuado, com população moderada de eosinófilos predominantemente em torno de vasos de maior calibre. O diagnóstico de choque anafilático foi baseado no histórico, em sinais clínicos $e$ em achados anatomopatológicos. Este é o primeiro relato de ataque de abelhas com infiltração eosinofílica pulmonar em um mamífero.

Palavras-chave: apitoxina, melitina, Apis mellifera mellifera, Apis mellifera scutellata

\section{INTRODUCTION}

Accidental bites due to Hymenoptera order insects occurs commonly in human beings (Langley and Morrow, 1997; Vetter et al., 1999), but are infrequently observed in veterinary routine (Fighera et al., 2007) and few cases are described in equines in Brazil (Fonteque et al., 2018; Ribeiro et al., 2020; Veado et al., 2020). Most important insects of that order are grouped into three superfamilies: Apoidea (honeybees, 20,000 species), Vespoidea (wasps, 15,000 species) and
Formicidae (ants, 15,000 species) (Fitzgerald and Flood, 2006). At venom glands, superfamily Apoidea species produces apitoxin, a protein rich aqueous solution with multiple peptides and vasomotor amines (Fitzgerald and Flood, 2006; Pitchon et al., 2014); which is delivered through the inoculation apparatus, called sting (Landim, 2009). Interbreeding of European honeybees (Apis mellifera mellifera) and African honeybees (Apis mellifera scutellata) resulted in a hybrid called the Africanized honeybee; more productive and resistant, however more aggressive with

*Corresponding author: alexandre.arenales88@gmail.com Submitted: August 15, 20. Accepted: August 9, 2021. 
swarm defense behavior (Sakate, 2008). Victims' reaction to this toxin is dependent on multiple conditions such as: inoculation via, amount of venom and previous sensibilization (Tizard, 2014).

Clinical signs vary greatly in domestic species, from type I hypersensitivity with local allergic reaction due to a few stings or anaphylactic shock in animals with more sensibility, to severe cases with massive swarm attack, resulting in toxic systemic reaction (Sakate, 2008) and type IV hypersensitivity with local granulomas (Mauldin and Peters-Kennedy, 2016). In equines, probable anaphylactic mediators are histamine and serotonin (Tizard, 2014). In Brazil, there are reports of honeybee attacks in various animal species (Caldas et al., 2013; Fonteque et al., 2018; Machado et al., 2018; Milbradt et al., 2017; Pessoa et al., 2014; Ribeiro et al., 2020; Souza, 2018; Veado et al., 2020), however, to the best of our knowledge, there are no reports of donkeys attacked by Africanized honeybees in this country, thus this paper aims to describe clinical and anatomic pathology changes in a case of anaphylactic shock due to few honeybee stings in a donkey.

\section{CASE REPORT}

Three equines, two adult female crossbred adult mares (144 and $270 \mathrm{~kg}$ ), and one adult male donkey $(260 \mathrm{~kg})$, were referred to the Clínica de Bovinos de Garanhuns, Universidade Federal Rural de Pernambuco (CBG/UFRPE) with a history of an Africanized honeybee swarm attack three hours beforehand. On physical examination, the horses had a stable clinical condition without noticeable cutaneous lesions and due to favorable prognosis, both were discharged with one dose of intravenous dexamethasone treatment $(0.1 \mathrm{mg} / \mathrm{kg})$ without any further problems. However, the donkey physical examination revealed ten large areas of cutaneous swelling, predominately at the head and neck, restless behavior, frequent lateral decubitus, congested sclera, cold extremities, tongue edema, inspiratory dyspnea, laryngotracheal stridor and tachycardia (60 BPM) were observed; additionally: severe dehydration $(10 \%),<2$ seconds of capillary refill time, lack of appetite and gastrointestinal tract hypomotility and bilateral flank bulging. Due to poor prognosis, this animal was hospitalized with intravenous dexamethasone $(0.1 \mathrm{mg} / \mathrm{kg})$ treatment, which was the only treatment possible at that time. It was not possible to remove stings and to collect blood for laboratory exams due to the donkey's very agitated behavior. However, the clinical condition was severely complicated, and death occurred a few hours later with a further necropsy procedure.

Gross lesions were moderate to severe multifocal to coalescent swelling, characterized by an increase in volume of cervical and facial skin, more visible in the submandibular and palpebral region (Fig. 1A), resulting in moderate facial asymmetry (Fig. 1B); cut surface of severe subcutaneous expansion with intensely red and gelatinous edema (Fig. 1C). Lungs were diffusely dark red with moderate parenchymal diffuse expansion, without collapse and abundant diffuse edema (Fig. 1D). Tissue samples were collected and fixed in $10 \%$ neutral formalin, processed for histopathology as routine, embedded in paraffin wax with $3 \mu \mathrm{m}$ thick cuts and stained for hematoxylin and eosin.

Microscopically, at skin, severe and diffuse enlargement of the deep dermis and panniculus carnosus, characterized by severe and diffuse edema with red blood cells, resulting in collagen and muscular fiber dissipation, and mild diffuse edema at superficial dermis with discrete collagen fiber dissipation and moderate vascular ectasia. Marked and diffuse alveolar edema with abundant eosinophilic homogeneous content at alveolar spaces (Fig. 2A); and diffuse, severe interalveolar septate hyperemia with occasional multiple foci of abundant infiltration of eosinophils, predominantly in large vessels perivascular regions and rarely at alveolar septate or alveolar spaces (Figs. 2B, 2C and 2D), also scarce multifocal areas of mild alveolar emphysema. Additionally, renal changes of rare foci in the cortical region with tubular epithelial necrosis and seldom intraluminal tubular cylinders composed of cellular debris. These macroscopic and microscopic changes in addition to the history and clinical data allowed to conclude the cause of death as an anaphylactic shock. 


\section{Zache et al.}

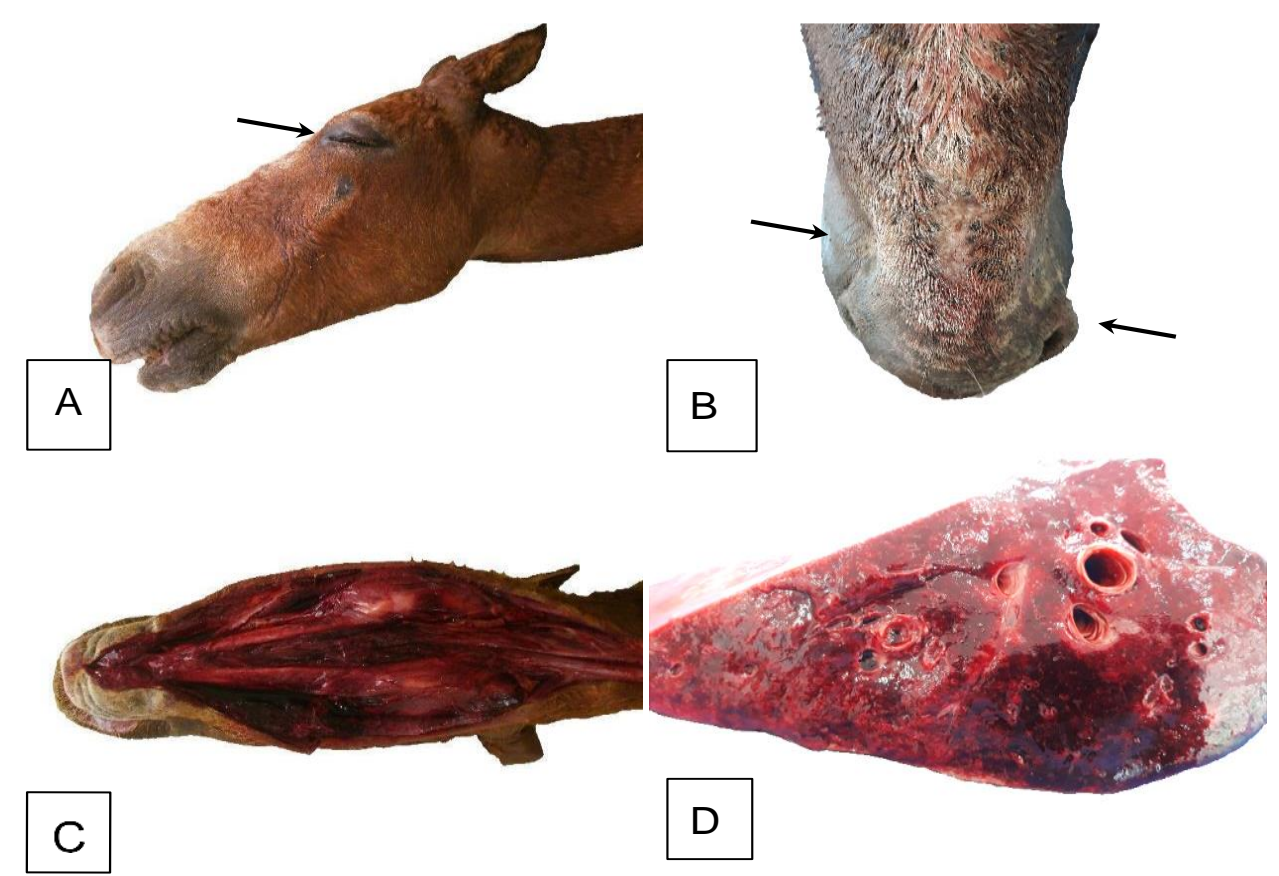

Figure 1. Macroscopic findings in a donkey attacked by Africanized honeybees 1A. Moderate facial skin swelling with severe palpebral edema. 1B. Facial asymmetry because of moderate, multifocal to coalescent facial skin swelling (arrows). 1C. Submandibular region, subcutaneous tissue with diffuse marked gelatinous red and abundant edema. 1D. Lung, diffuse and severe parenchymal reddish, abundant edema without collapse.

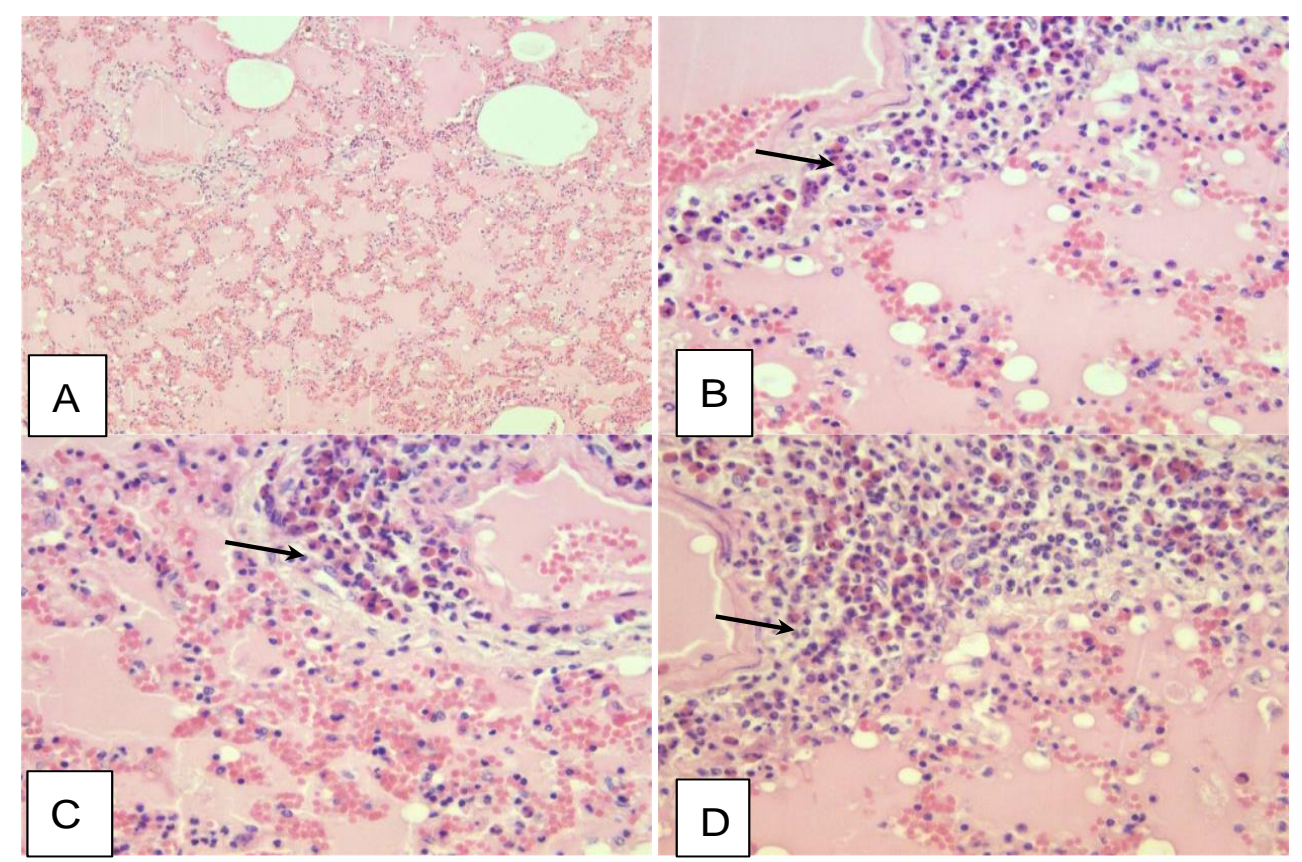

Figure 2. Microscopic findings in a donkey attacked by Africanized honeybees. 2A. Marked diffuse alveolar edema with intense hyperemia and scarce mild multifocal emphysema. 100x, Hematoxylin and eosin. 2B, 2C and 2D. Moderate infiltration of eosinophils around blood vessels (arrows). These cells are rarely at alveolar septate or alveolar spaces 400x. Hematoxylin and eosin. 


\section{DISCUSSION}

A case of an anaphylactic shock is described in a donkey due to apitoxin inoculated by an Africanized honeybee attack with a unique finding of eosinophilic pulmonary infiltration. The diagnosis was made based on history, clinical signs, and anatomic pathologic findings; and this is the first report of those findings in a mammal. This severe clinical condition may be a consequence of a possible donkey's sensitivity to the venom or simply by the fact that the donkey was more severely affected than the mares.

Lungs described here are compatible with an anaphylactic shock consequence (Ribeiro et al., 2020; Veado et al., 2020), however microscopic finding of eosinophilic infiltration are probably associated with massive dermal and pulmonary mast cell degranulation and abrupt proinflammatory mediator release; resulting in chemotaxis for an abundant eosinophils population, obviously from blood vessels, explaining perivascular localization of those cells. Finally, when vasoactive molecules exceed the vascular system's adjustment capacity, anaphylaxis occurs (Tizard, 2014).

Interestingly, only one report of a honeybee attack in Psittacidae cites pulmonary eosinophilic infiltration (Milbradt et al., 2017). Lungs are described as the main organ for shock in horses (Tizard, 2014); thus, it is plausible that type I hypersensitivity and pulmonary changes were sufficient to result in this animal death, however apitoxin cardiotoxic is probably involved as well; mainly due to mild and clinically insignificant microscopic tubular epithelial necrosis in kidneys. In contrast, animals with prolonged clinical signs present important renal lesions due to hypoxia caused by venom nephrotoxicity and hypotension by vasoactive components, both resulting in acute tubular necrosis (Ribeiro et al., 2020; Sakate, 2008).

Despite a lack of laryngeal and tracheal lesions, cutaneous findings in the present case are similar to those previously reported, regardless of the animal species, as in dogs (Machado et al., 2018; Mughal et al., 2014; Nair et al., 2019; Souza, 2018), horses (Fonteque et al., 2018; Ribeiro et al., 2020; Veado et al., 2020), mules (Mahmoudi et al., 2014), ovines (Veado et al., 2020) and Psittacidae (Milbradt et al., 2017). Nevertheless, the other two horses reported here did not have further signs after treatment, maybe due to a greater resistance in contrast to reports of alopecia and skin necrosis at sting sites (Fonteque et al., 2018; Lewis and Racklyeft, 2014; Veado et al., 2020) or even skin shedding seven days after the stings (Caldas et al., 2013).

\section{CONCLUSION}

In conclusion, the history, clinical and anatomopathological findings were central for the diagnostic conclusion in this case and pulmonary eosinophilic perivascular infiltration should be considered as a microscopic finding in anaphylactic shock and death due to honeybee attacks in donkeys.

\section{REFERENCES}

CALDAS, S.A.; GRAÇA, F.A.S.; BARROS, J.S.M. et al. Lesions caused by Africanized honeybee stings in three cattle in Brazil. J. Venom. Anim. Toxins. Incl. Trop. Dis., v.19, p.1-5, 2013.

FIGHERA, R.A.; SOUZA, T.M.; BARROS, C.S.L. Acidente provocado por picada de abelhas como causa de morte de cães. Cienc. Rural, v.37, p.590-593, 2007.

FITZGERALD, K.T.; FLOOD, A.A. Hymenoptera stings. Clin. Tech. Small Anim. Pract., v.21, p.194-204, 2006.

FONTEQUE, J.H.; MENDES, R.P.; SOUZA, A.F. et al. Systemic toxic reaction due to multiple honeybee stings in equine: case report. Arq. Bras. Med. Vet. Zootec., v. 70, p.767-772, 2018.

LANDIM, C.C. Abelhas: morfologia e função de sistemas. São Paulo: UNESP, 2009. p.371-378.

LANGLEY, R.L.; MORROW, W.E. Deaths resulting from animal attacks in the United States. Wilderness Environ. Med., v.8, p.8-16, 1997.

LEWIS, N.; RACKLYEFT, D.J. Mass envenomation of a mare and foal by bees. Aust. Vet. J., v.92, p.141-148, 2014.

MACHADO, M.; SOUSA, D.E.R.; LANDI, M.F.A. et al. Reação tóxica sistêmica causada por picadas de abelhas em cães. Acta. Sci. Vet., v.46, p.271, 2018 . 
MAHMOUDI, M.; SOOREH, A.A.; KAHROBA, E. Anaphylaxis due to stings of Apis Mellifera Meda (Iranian honeybee) in two mules. Pferdeheilkunde, v.30, p.191-194, 2014.

MAULDIN, E.A.; PETERS-KENNEDY, J. Integumentary system. In: MAXIE, M.G. (Ed.). Jubb, Kennedy and Palmer's pathology of domestic animals. Missouri: Elsevier; 2016. p.509-736.

MILBRADT, E.L.; SILVA, T.M.; HATAKA. A. et al. Massive attack of honeybee on macaws (Ara ararauna and Ara chloropterus) in Brazil - a case report. Toxicon, v.136, p.1-5, 2017.

MUGHAL, M.N.; ABBAS, G.; SAQIB, M. et al. Massive attack by honeybees in a German shepherd dog: Description of a fatal case and review of the literature. J. Venom. Anim. Toxins. Incl. Trop. Dis., v.20, p.55, 2014.

NAIR, R.; RIDDLE, E.A.; THRALL, M.A. Hemolytic anemia, spherocytosis, and thrombocytopenia associated with honey bee envenomation in a dog. Vet. Clin. Pathol., v.48, p.620-623, 2019.

PESSOA, A.F.A.; PESSOA, C.R.D.M.; MIRANDA NETO, E.G. et al. Doenças de asininos e muares no semiárido brasileiro. Pesqui. Vet. Bras., v.34, p.1231-1235, 2014.
PITCHON, R.; REIS, A.P.; SILVA, G.D.C.G. et al. Alergia a himenópteros: do ambulatório à urgência. Rev. Med. Minas Gerais, v. 24, p.6-12, 2014.

RIBEIRO, P.R.; BIANCHI, M.V.; HENKER, L.C. et al. Acute renal failure in a horse following bee sting toxicity. Cienc. Rural, v.50, p.1-5, 2020.

SAKATE, M. Zootoxinas. In: SPINOSA, H.S.; GÓRNIAC, S.L.; PALERMO-NETO J. (Eds.). Toxicologia aplicada à medicina veterinária. São Paulo: Manole, 2008. p.209-255.

SOUZA, J.M.S. Toxicose por picada de abelhas em cão. PubVet, v.12, p.1-3, 2018.

TIZARD, I.R. Imunologia veterinária. Rio de Janeiro: Elsevier, 2014. 552p.

VEADO, H.C.; CONCEIÇÃO, R.S.; NOGUEIRA, K. et al. Massive Africanized honeybee stings in two hair sheep and a mare. Toxicon, v.177, p.35-40, 2020.

VETTER, R.S.; VISSCHER, P.K.; CAMAZINE, S. Mass envenomations by honey bees and wasps. West. J. Med., v.170, p.223-227, 1999. 